\title{
Short Communication: Mosses from Laiwangi-Wanggameti National Park, Sumba, East Nusa Tenggara, Indonesia
}

\author{
FLORENTINA INDAH WINDADRI", DEWI ROSALINA \\ Research Center for Biology, Indonesian Institute of Sciences. Jl. Raya Jakarta-Bogor Km. 46, Cibinong, Bogor 16911, West Java, Indonesia. \\ Tel.: +62-21-8765066, ’email: floren_windadri@yahoo.co.id
}

Manuscript received: 8 November 2019. Revision accepted: 15 January 2020

\begin{abstract}
Windadri FI, Rosalina D. 2020. Short Communication: Mosses from Laiwangi-Wanggameti National Park, Sumba, East Nusa Tenggara, Indonesia. Biodiversitas 21: 538-545. Sumba Island is an island within the Lesser Sunda Islands. Despite the high diversity and the uniqueness of the area, research to explore the biodiversity in the national park have been rarely conducted. This study was aimed to do inventory of mosses diversity in Laiwangi-Wanggameti National Park, Sumba Island, East Nusa Tenggara Province to enrich the limited information regarding biodiversity in the region. The inventory was done using explorative methods at two research sites (i.e. Laiwangi and Wanggameti), mainly around lake, along river banks, stream banks, site of mount tracking trail and forests. All the mosses found in the study site were collected and then identified based on existing literature and herbarium records. We found 33 species of mosses belonging to 24 genera and 16 families. There were 22 species that shared similarity between Sumba Island and the Lesser Sunda Islands. We proposed that there were 11species of mosses as new records of their distribution in the Lesser Sunda Islands. The ecology and taxonomical status of mosses in the study sites were also described in this paper
\end{abstract}

Keywords: Diversity, Laiwangi-Wanggameti National Park, moss, Sumba

\section{INTRODUCTION}

Sumba Island is one of big islands in East Nusa Tenggara Province, Indonesia. This province along with two other provinces (i.e. Bali and West Nusa Tenggara) are often biogeographically grouped as Lesser Sunda Islands. Sumba Island has two conservation areas in the form of national parks, namely Manupeu-Tanah Daru and Laiwangi-Wanggameti. Laiwangi-Wanggameti is a newly established national park in Sumba Island, being declared as a national park in 1998 through the decree of Minister of Forestry No. 576/Kpts-II/1998. This national park is located $100 \mathrm{~km}$ from Waingapu, the capital of East Sumba District. Besides its purpose for biodiversity conservation, the national park also serves as the main water catchment area used for irrigation of agricultural lands and sources of clean water for Waingapu.

The general topography of Laiwangi-Wanggameti National Park is hilly, with rather steep slopes to extremely steep. A flat to undulating topography is located on the southeast and south, while in the west and east it has a hilly to mountainous topography with slopes having a bit steep to very steep. Ecosystem types in Laiwanggi-Wanggameti National Park include mangrove forests, coastal forests, dry tropical rain forests and lowland rain forests to mountain rain forests. The annual rainfall is $100-500 \mathrm{~mm}$ based on Schmidt-Ferguson classification system with the Wanggameti forest is classified as a rather wet climate with humidity up to $71 \%$. The forest floor in Wanggameti is slightly open and the tree closure is rather tight (BTNLW 2013).
This conservation area has high biological diversity in which $60 \%$ of the area are steppes and $40 \%$ low land forest and elfin forest with high diversity is commonly found at the altitude of $800 \mathrm{~m}$ as 1 . Despite the high diversity and the uniqueness of the area, research to explore biodiversity in the national park has been rarely conducted. Biodiversity research that has been done in this national park included inventory of fern by Darma and Peneng (2007). Yet, other research on other taxonomical groups, for example, moss inventory, has never been done.

In general, botanical research on mosses in Sumba Island never intensively done. It is shown from the Touw's report (1992) that only one species was collected from Yawila Mount in West Sumba by Verheijen (4097), namely Leucobryum sanctum. Data and information on mosses diversity of Sumba Island are very limited so it needs to be carried out an inventory mainly on the conservation areas. This study was aimed to do inventory of mosses diversity in Laiwangi-Wanggameti National Park, Sumba Island, East Nusa Tenggara Province to enrich the limited information regarding biodiversity in the region.

\section{MATERIALS AND METHODS}

\section{Study area and period}

Moss inventory was carried out in LaiwangiWanggameti National Park, East Sumba District, East Nusa Tenggara Province, Indonesia, on geographic position of $09^{\circ} 59^{\prime} 15.8^{\prime \prime}-10^{\circ} 06^{\prime} 59.1$ 'S and $120^{\circ} 03^{\prime} 26.3^{\prime \prime}-120^{\circ} 15^{\prime} 21^{\prime \prime} \mathrm{E}$. 
Moss collection was a part of Widya Nusantara Expedition activities carried out from April to May 2016 in Sumba Island. The moss collections were conducted on two locations, namely Laiwangi study site and Wanggameti study site. In Laiwangi study site, inventory was done around lake site and waterfall of Lauputi, Luku Ahu River, Waewau and Tanah Bara at altitudes of $340-560 \mathrm{~m}$. While in Wanggameti study site, inventory was done on Ramuk and Watumbelar rivers site, forest surrounding tracking trail and top of Wanggameti Mount at altitudes of 1024$1225 \mathrm{~m}$ asl.

\section{Mosses sampling and identification}

The inventory was done using exploration method at all the research sites, mainly around lake, along river banks, stream banks, site of mount tracking trail and forests. All the moss found in the study site were collected. Moss samples were inserted into envelope made from used newspapers and the primary data such as initial collector, collection-number, dates, and locations were written on the outside of the envelope. Environmental data such as substrate, $\mathrm{pH}$, air humidity, temperature, and environmental conditions were recorded in the field book. All mosses samples were identified using some references such as Bartram (1939), Eddy (1988, 1990, 1996), So (1995), Zhu and So (1995), Rosario (1979) and the Herbarium Bogoriense (BO) mosses specimen collections. All mosses that have been identified were processed as herbarium collections and were stored in the Herbarium Bogoriense, Bogor, Indonesia. The distribution tracking of all mosses in the study sites was done manually or digitally to determine the taxonomical status.

\section{RESULTS AND DISCUSSION}

\section{The ecology and distribution of mosses in Laiwangi- Wanggameti National Park}

The total number of samples collected from the national park were 156 collection numbers and identified as 33 species of true moss, consisting of 14 species from Laiwangi and 22 species from Wanggameti. There were 3 species of mosses which were found in both research locations (Figure. 2)

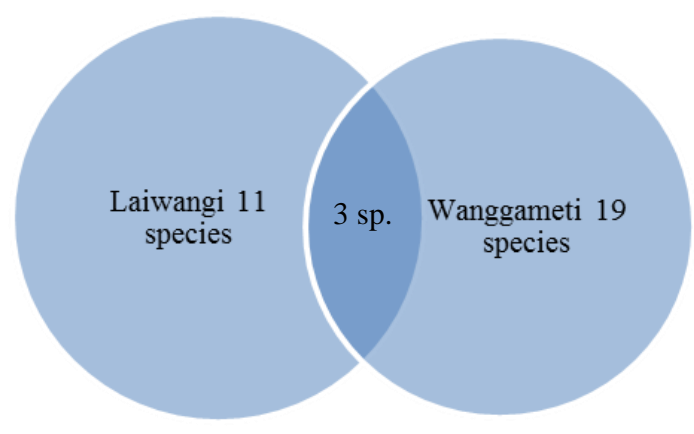

Figure 2. The diversity of mosses collected from Laiwangi and Wanggameti study sites

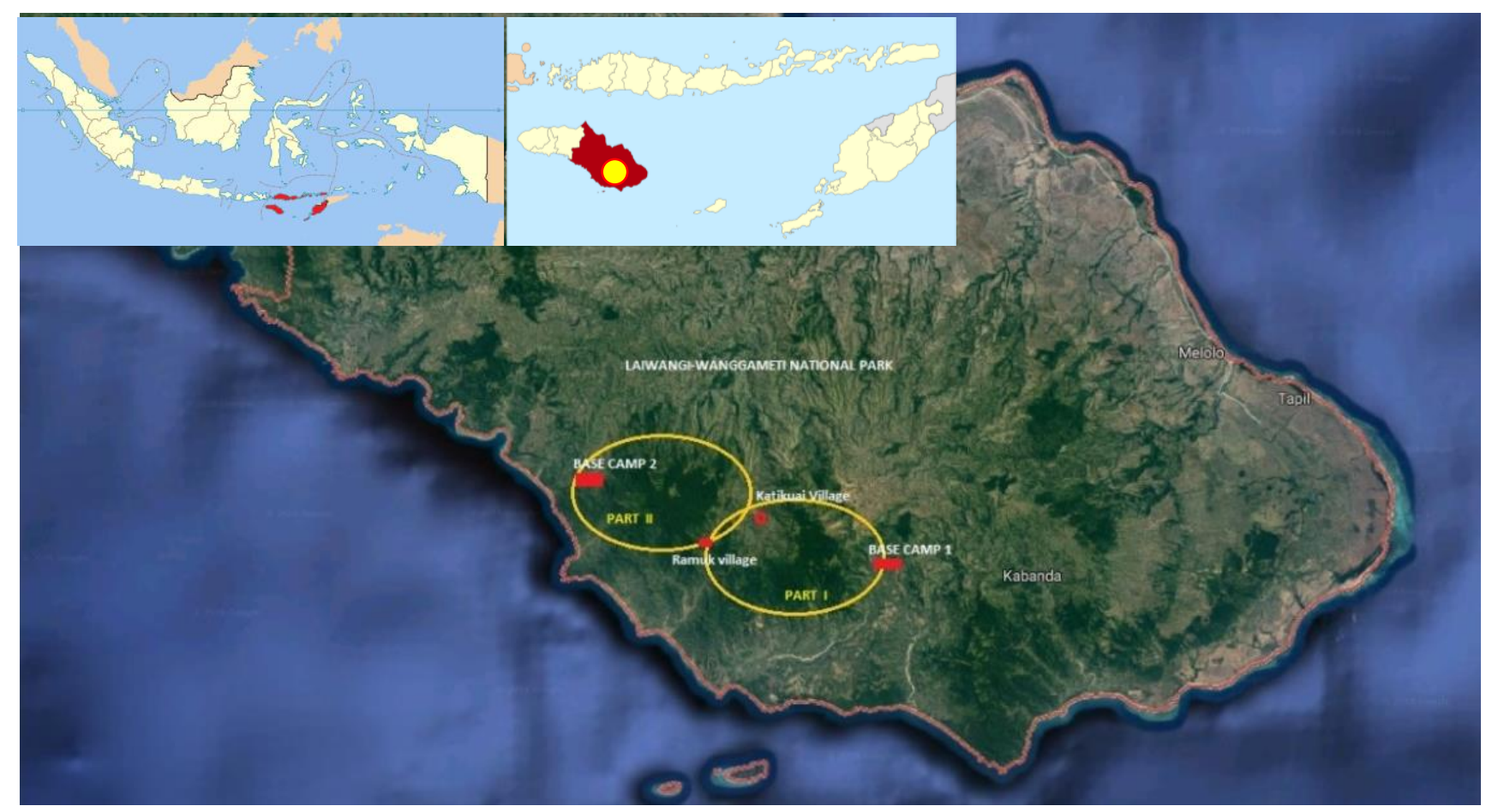

Figure 1. Map of study site in Laiwangi-Wanggameti National Park (Sumba Island), East Sumba District, East Nusa Tenggara Province, Indonesia 


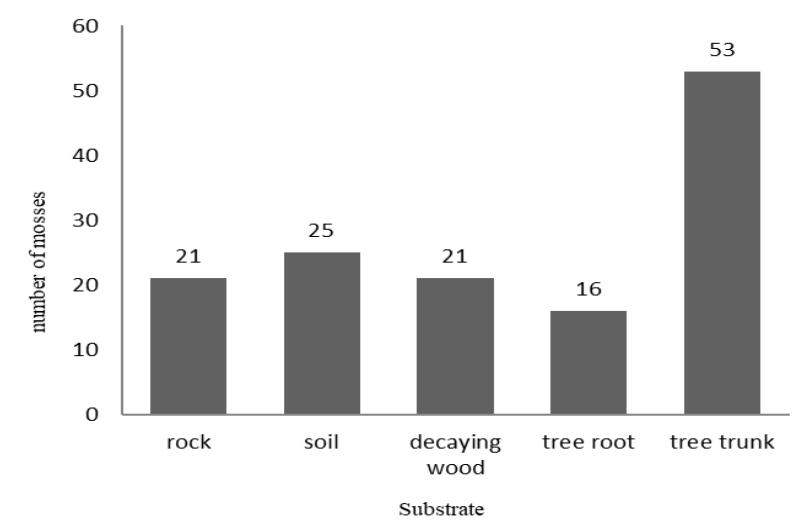

Figure 3. Substrates where moss grew at Laiwangi-Wanggameti National Park

Table 1. Result of environmental parameters of the study sites in the Laiwangi-Wanggameti National Park

\begin{tabular}{lll}
\hline Parameter & \multicolumn{2}{l}{ Location / measurement value } \\
\cline { 2 - 3 } & Laiwangi & Wanggameti \\
\hline Altitude & $482-563 \mathrm{~m}$ asl & $1113-1225 \mathrm{~m}$ asl \\
Slope & $30-40 \%$ & $50-60 \%$ \\
Temperature & $27-31^{\circ} \mathrm{C}$ & $22-25^{\circ} \mathrm{C}$ \\
Air humidity & $53-66 \%$ & $73-86 \%$ \\
Light intensity & - & $<16001 \mathrm{lu}$ \\
pH & - & $6.2-6.9$ \\
Soil humidity & - & $60-90 \%$ \\
\hline
\end{tabular}

Moss in Laiwangi-Wanggameti National Park grows on various substrates including soil, stone, tree roots, decaying wood and tree trunks as presented in Figure 3. Most of the bryophytes of the rainforest are epiphytes (Frahm \& Gradstein, 1991) so they need a substrate for growth. Tree trunk is a stabile substrate, so in this study, tree trunk was the most covered substrate by mosses. On the other hand, mosses grew on the other substrates, such as soil, stone, decaying wood, and tree root, they will be easily washed away by rainwater or harsh winds, especially in steep places such as at study sites with a slope of up to $60 \%$ (Table 1). Growth and development of mosses also related to environmental factors as presented in Table 2.

Our study showed that moss diversity in Wanggameti was higher than in Laiwangi. This was likely because the location of the forest in Wanggameti was higher (alt. 1024$1225 \mathrm{~m}$ ), had higher humidity and lower light intensity as the result of the high density of trees and canopies. This finding is consistent with Frahm \& Gradstein (1991) that stated phytomass and species number of bryophyte in the sub mountain forest are slightly higher than in the lowland forest. There were 3 species of mosses found at both research sites, namely Fissidens robinsonii Broth. (syn. Fissidens crispulus var robinsonii), Himantocladium plumula (Nees) M. Fleisch., and Octoblepharum albidum Hedw, suggesting that the three species of mosses have a wide range of habitat. In New Zealand, Fissidens robinsonii is reported to grow on the wet rocks in shaded places at altitudes of 150-320 m asl (Breever 2014), but in our study side, this species was found on wet soils at altitude of 482-521 m asl (Laiwangi site, DR 476 \& 530) and also at altitude $1024 \mathrm{~m}$ asl (Wanggameti site, DR 313) in the shade areas. The presence of this species at both study sites implies that altitude and growth substrate does not affect its presence in natural habitat, but the influencing factor is likely humidity and temperature. Temperate region usually has low temperature, while tropic has higher temperature. At the study site in Wanggameti forest, the temperature was $22-25^{\circ} \mathrm{C}$, the humidity was $73-86 \%$ and $60-90 \%$ for air and soil, respectively. On the other hand, Himantocladium plumula and Octoblepharum albidum have wide distribution, ranging from near sea level to 1700 m (Eddy 1990; Enroth 1992). In the study sites, these mosses were found at altitude $536 \mathrm{~m}$ asl (Laiwangi, DR 523) and $1126 \mathrm{~m}$ asl (Wanggameti, DR 335).

The diversity of mosses on Sumba Island can not be separated from the diversity in the surrounding islands. The mosses diversity in the Lesser Sunda Islands were reported about 367 species (Touw 1992), including one species from Sumba Island (Yawila Mount, West Sumba). When compared with diversity mosses in the Lesser Sunda Islands as described by Touw (1992), there are 22 species that share similarities with that in Sumba Island (Table 1). As such, this study suggests that there are 11 species proposed as new records of the distribution in Lesser Sunda Islands. The similarity of moss species in the study site with other islands around it because the moss spores are very small size and easily spread by wind or water.

As shown in Table 2 the greatest similarity of moss species diversity between the study sites other regions in Lesser Sunda Islands is Flores (located north-east of Sumba Island) with 22 species. Mosses diversity from Flores Island is reported to have 278 species (Touw 1992). The result of our study suggests that in addition to the closeness between the islands, the environmental factors are almost same which suitable for growth of the moss. For example, Pyrrhobryum spiniforme has wide range of substrates and in this study, it was found in soil, decaying wood, rocks or the base of tree trunks in forests. Gilmore (2012) reported that it also has wide range of distribution, from Central and South America, Hawaii Islands, Africa, SE Asia, Malesia, and Howe Island. In Indonesia, it spreads from Sumatra to New Guinea. In the Lesser Sunda Islands region, this species is found in almost all islands.

\section{Taxonomical status of mosses from Laiwangi- Wanggameti National Park}

We found 33 species of 24 genera and 16 families from the two study sites. A description of the taxonomical status of mosses at the study site will be described as follows. The list of mosses diversity was written alphabetically in sequence family, genus, species and the author name; substrate and location of collection, collector and collection number; and Malesiana distribution. The known distributions were based on some references including Windadri (2019), He (2019), Eddy (1988, 1990, 1996), Touw (1992), Bartram (1939), and other publications related to mosses diversity at the study sites. "DR" is the initial name of collector, Dewi Rosalina. New record of the species on Lesser Sunda Islands moss was indicated by an asterisk ("*") in front of the species name. 
Table 2. Comparison of the moss species from the two study sites with other islands in Lesser Sunda Islands (Touw 1992)

\begin{tabular}{|c|c|c|c|c|c|c|c|c|c|}
\hline \multirow{2}{*}{ Family } & \multirow{2}{*}{ Species name } & \multicolumn{8}{|c|}{ Islands name } \\
\hline & & B & $\mathbf{L}$ & SBW & SB & $\mathbf{F}$ & $\mathbf{T}$ & $\mathbf{A}$ & $\mathbf{K}$ \\
\hline Bartramiaceae & Philonotis bartramioides (Griff.) Griffin \& Bruck & & & & + & + & & & \\
\hline Brachytheciaceae & Rhynchostegium celebicum (Sande Lac.) A. Jaeger & & & + & + & + & & & \\
\hline Calymperaceae & Calymperes afzelii Sw. & + & & & + & + & & & \\
\hline \multirow[t]{2}{*}{ Calymperaceae } & Mitthyridium flavum (Mull.Hal.) Rob. & + & & & + & + & & & \\
\hline & Syrrhopodon aristifolius Mitt. & + & & & + & + & & & \\
\hline \multirow[t]{2}{*}{ Dicranaceae } & Leucobryum candidum (P. Beauv.) Wils. & & & & + & + & & & \\
\hline & Leucobryum juniperoideum (Brid.) Mull.Hal.. & & + & & + & & & & \\
\hline \multirow[t]{3}{*}{ Hypnaceae } & Ectropothecium dealbatum (Hornsch. and Reinw.) A.Jaeger & + & & & + & & & & \\
\hline & Ectropothecium falciforme (Dozy \&Molk.) A. Jaeger & & + & & + & & & & \\
\hline & Ectropothecium ichnotocladum (Mull. Hal.) A. Jaeger & + & & & + & & & & \\
\hline \multirow[t]{2}{*}{ Meteoriaceae } & Aerobryopsis wallichii (Brid.) M. Fleisch. & + & + & + & + & + & & & \\
\hline & Meteorium polytrichum Dozy \&Molk. & + & + & + & + & + & + & & \\
\hline \multirow[t]{3}{*}{ Neckeraceae } & Himanthocladium plumula (Nees) M. Fleisch. & + & + & & + & + & & & \\
\hline & Neckeropsis gracilenta (Bosch \& Sande Lac.) M. Fleisch. & & + & & + & + & & & \\
\hline & Neckeropsis lepineana (Mont.) M. Fleisch. & + & + & + & + & + & + & & \\
\hline Octoblepharaceae & Octoblepharum albidum Hedw & & & + & + & + & + & & + \\
\hline Polytrichaceae & Pogonatum neesii (Müll. Hal.) Dozy \&Molk. & + & & + & + & + & + & & \\
\hline Pterobryaceae & Pterobryopsis crassicaulis (Müll. Hal.) M. Fleisch. & & & & + & + & & & \\
\hline Rhizogoniaceae & Pyrrhobryum spiniforme (Hedw.) Mitt. & + & + & + & + & + & + & + & \\
\hline \multirow[t]{2}{*}{ Sematophyllaceae } & Taxithelium kerianum (Broth.) Broth. & + & & & + & + & & & \\
\hline & Taxithelium vernieri (Duby) Besch. & & & & + & + & & & \\
\hline Thuidiaceae & Thuidium plumulosum (Dozy \&Molk.) Dozy \& Molk. & & & & + & + & & & \\
\hline Total & & 12 & 8 & 7 & 21 & 18 & 6 & 1 & 1 \\
\hline
\end{tabular}

Note: +: the presence of moss species. The island names: B: Bali; L: Lombok; SBW: Sumbawa; SB: Sumba; F: Flores; T: Timor; A: Alor; K: Komodo

\section{Artificial key to family}

1a. Plant usually with erect stem (Acrocapous mosses)

b. Plant with creeping or pendulous stems (Pleurocarpous mosses)

\section{2} .. 11

2a. Plant with whitish green color, iridescent when dry .................................................. Octoblepharaceae

b. Plant with pale to dark color $\ldots \ldots \ldots \ldots \ldots \ldots \ldots \ldots \ldots . . . \ldots, 3$

3a. Stem simple, usually with lower and upper leaves differentiated, Lower leaves small, often scale-like, appressed, remote; upper leaves larger, often crowded, with a broad pale unistratose sheathing base and a narrow lamina .......................... Polytrichaceae

b. Stem simple or branched, leaves simple or with

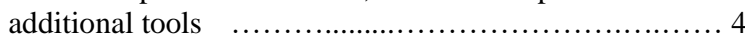

4a. Leaves equitant and distichous ............... Fissidentaceae

b. Leaves in 2 or more rows, often complanate,

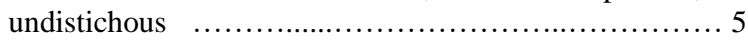

5a. Leaf with inner basal cell large and empty, sharply differentiated from the small chlorophyllous cells of

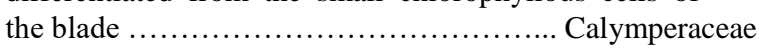

b. Inner basal cell of leaf conspicuously undifferentiated



6a. Plants small to large, often in dense tufts; leaves with single costa, strong, percurrent or excurrent b. Plants small to medium-sized, leaves with costa single, double or none .......................................... 8

7a. Leaves in several rows around the stem, erect or secund, often falcate-secund, sometimes crispate, short-to long-lanceolate, asexual reproduction occasionally present as brood leaves, microphyllous branches, borne in axils of distal leaves or as rhizoidal tubers, sexual reproduction as sporophyte with single or several seta per perichaetium ............ Dicranaceae

b. Leaves imbricate to widely spaced, erect-spreading to squarrose, linear-lanceolate to ovate-lanceolate; asexual reproduction unknown, sexual reproduction as sporophyte with single seta per perichaetium Rhizogoniaceae

8a. Capsule erect with calyptra mitrate, hairy ... Polytrichaceae

b. Capsule erect, inclined, horizontal with calyptra cucullate, smooth

9a. Seta straight, smooth, operculum conical ............. 10

b. Seta solitary, elongate, often twisted, operculum short conic to short rostrate $\quad . . . \ldots \ldots \ldots . . . \ldots \ldots$........ Pottiaceae

10a. Capsule subglobose or ovoid, usually asymmetric, furrowed or rarely smooth or irregularly wrinkled when dry, peristome double .............. Bartramiaceae

b. Capsule globose, symmetrically, peristome single .................................... Splachnaceae

11a. Stems with regularly pinnate branches $\ldots \ldots \ldots \ldots \ldots \ldots 12$

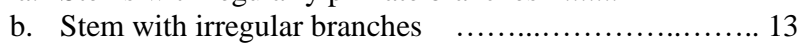


12a. Leaves differentiated in stolon leaves scale-like with apex short-acute or long-acuminate, usually ecostate; Stipe leaves appressed, triangular to ovate-acuminate, costa double or single, shorter in stem leaves; Stem leaves ovate-acuminate, ovate-orbicular, oblonglanceolate, oblong-ovate, or ovate-lanceolate, costa single or double and short. Seta red-brown, elongate, capsule erect, exserted, red-brown, calyptra cucullate, fully or partly covering capsule ............. Pterobryaceae

b. Leaves differentiated in stem leaves that mostly strongly differing in size and shape from branch leaves, mostly triangular or broadly triangular, mostly longitudinally plicate, often ending in a pluricellular uniseriate hair, costa single, strong, rarely reaching the leaf tip; branch leaf with costa shorter, more often projecting abaxially, margin recurved below. Seta usually smooth, mammillose or spinose, capsules mostly weakly curved, Calyptra either cucullate or campanulate and scabrous or bearing long bristles

Thuidiaceae

13a. Stem and branch leaves differentiated; it has asexual reproduction by flagelliferous branches or axillary filamentous propagula .................. Sematophyllaceae

b. Stem and branch leaves similar; without asexual reproduction ........................................ 14

14a. Leaves often falcate-secund, often asymmetric at base, margins occasionally recurved proximally or throughout, costa double, short, to obscure or ecostate Hypnaceae

b. Leaves ovate-lanceolate, erect spreading, costa single, percurrent or excurrent

15a. Leaves with auriculate or cordate based, margin denticulate or dentate, Laminal cells usually papillose; Seta short, often exserted, smooth, capsules emergent, erect, ovate to oblong, operculum tall, conical or rostrate, curved ............................. Meteoriaceae

b. Leaves plicate or undulate; Laminal cells narrowly rectangular throughout, or upper laminal cells isodiametric to oblong, oval or rhomboidal; intramarginal cymbidium occasionally present, consisting of longer cells; sporophyte lateral on branches Neckeraceae

\section{List of mosses from Laiwangi-Wanggameti National Park.}

\section{Bartramiaceae}

Philonotis bartramioides (Griff.) Griff \& Buck.

Laiwangi site, S $10^{\circ} 03^{\prime} 46.7^{\prime \prime}$ E $120^{\circ} 04^{\prime} 21.7^{\prime \prime}$, Alt. 375

m, on rock, DR 506.

Malesiana dist.: Java, Lesser Sunda Islands (Flores), Philippines, Sumatra

\section{Brachytheciceae}

Rhynchostegium celebicum (Sande Lac.) A. Jaeger

Laiwangi site, S 1001'21.2" E 12003'26.3", Alt 491 m, on soil around the waterfall, DR 481

Malesiana Dist. Lesser Sunda Islands (Bali, Flores, Timor), Malaysia, Philippine

\section{Calymperaceae}

Calymperes afzelii Sw.
Laiwangi region, S 1002'20.6" E 12003'37.1", Alt. $560 \mathrm{~m}$, on bark, DR 515

Malesiana Distr. Borneo, Celebes, Java, Lesser Sunda Islands (Lombok, Sumbawa, Flores), Malaysia, New Guinea, Philippine.

Mitthyridium flavum (Müll. Hal.) H. Rob.

Tracking trail to Mount Wanggameti, Alt. $1153 \mathrm{~m}$, on bark, DR 360

Malesiana Distr. Borneo, Java, Lesser Sunda Islands (Bali, Flores), Malaysia, New Guinea, Philippines, Singapore, Sumatra.

\section{Syrrhopodon aristifolius Mitt.}

Tracking trail to Mount Wanggameti, Alt. $1115 \mathrm{~m}$, on bark, DR 346

Malesiana Distr. Widespread in Malesia and Polynesia, but apparently endemic to those regions. In Lesser Sunda Islands reported at Bali and Flores

\section{Dicranaceae}

Leucobryum candidum (P. Beauv.)Wils.

Tracking trail to Mount Wanggameti, Alt. $1133 \mathrm{~m}$, on bark, DR 345

Malesiana Distr. Widespread in Malesia at lowland forest in the southeastern regions. In Lesser Sunda Islands reported from Flores

Leucobryum juniperoideum (Brid.) Müll. Hal.

Tracking trail to Mount Wanggameti, Alt. 1133 m, on decaying wood, DR $343 \& 369$

Malesiana Distr. Borneo, Celebes, Java, Lesser Sunda Islands (Lombok), Malaya Peninsula, Papua New Guinea, Philippines, Sumatra

* Leucoloma mittenii M. Fleisch.

Tracking trail to Mount Wanggameti, on decaying wood, DR 370

Malesiana Distr. Malay Peninsula

\section{Fisidentaceae}

* Fissidens perpusillus Wils. Ex Mitt.

Tracking trail to Mount Wanggameti, Alt. $1114 \mathrm{~m}$, on tree root, DR 316

Malesiana Distr. Borneo, Java, Malaysia, Philippines, Sri Lanka, Sumatra

* Fissidens robinsonii Broth.

Laiwangi site, S 0959'15.8" E $120^{\circ} 05^{\prime} 00.5^{\prime \prime}$, Alt. $482 \mathrm{~m}$ and around Laputi river, S 1001'93.6" E 120 03'47.8" Alt. $521 \mathrm{~m}$, on soil DR $476 \& 530$; also in tracking trail to Mount Wanggameti, Alt. 1024m, on soil, DR 313

Malesiana distr. endemic in Malesia and Polynesia

\section{Hypnaceae}

Ectropothecium dealbatum (Reinw. \& Hornsch.) A. Jaege

Tracking trail to Mount Wanggameti, Alt. $1024 \mathrm{~m}$, on decaying wood, DR 312

Malesiana Distr. Borneo, Java, Lesser Sunda Islands (Bali, Lombok), Philippines, Sumatra 
Ectropothecium falciforme (Dozy \& Molk.) A. Jaeger

Laiwangi site, S 1002'20.6" E 12003'37.1", Alt. 560

$\mathrm{m}$, on rock in the forest, DR 512

Malesiana Distr. Borneo, Celebes, Lesser Sunda Islands (Lombok), Java, Sumatra

Ectropothecium ichnotocladum (Müll. Hal.) A. Jaeger

Laiwangi site, S $10^{\circ} 01^{\prime} 21.2^{\prime \prime}$ E $120^{\circ} 03^{\prime} 26.3^{\prime \prime}$, alt. 491

$\mathrm{m}$, on decaying wood near waterfall, DR 483

Malesiana Distr. Borneo, Celebes, Java, Lesser Sunda

Islands (Bali, Lombok), Malaysia, Philippines, Sumatra

* Ectropothecium monumentorum (Duby) A. Jaeger 347

Tracking trail to Mount Wanggameti, on tree root, DR

Malesiana Distr. Borneo, Java, Malay Peninsula,

Philippines, Sumatra

* Isopterygium bancanum (Sande Lac.) A. Jaeger

Laiwangi site, S 1003'46.7" E 12004'21.7" Alt. 375

$\mathrm{m}$, on rock in the forest; DR 503

Malesiana Distr. Borneo, Celebes, Java, Malaysia, New

Guinea, Philippines, Sumatra

\section{Meteoriaceae}

Aerobryopsis wallichii (Brid.) M. Fleisch.

Tracking trail to Mount Wanggameti, Alt. $1124 \mathrm{~m}, \mathrm{~S}$ $10^{\circ} 04^{\prime} 37.3^{\prime \prime} \mathrm{E} 120^{\circ} 15^{\prime} 21.0^{\prime \prime}$ on tree root and bark, DR 317 , 353

Malesiana Distr. Borneo, Java, Lesser Sunda Islands (Bali, Lombok, Sumbawa, Flores), Malay Peninsula, New Guinea, Philippines, Sumatra

\section{Meteorium polytrichum Dozy \& Molk.}

Tracking trail to Mount Wanggameti, Alt. $1156 \mathrm{~m}$, on twigs of small tree, DR 357

Malesiana Distr. Borneo, Java, Lesser Sunda Islands (Bali, Lombok, Sumbawa, Flores, Timor), Malaysia, New Guinea, Philippines, Sumatra

\section{Neckeraceae}

*Himantocladium loriforme (Bosch \& Sande Lac.) M. Fleisch.

Tracking trail to Mount WanggametiAlt.1133-1150 m, on bark, DR $342 \& 358$

Malesiana Distr. Borneo, Celebes, Java, Laos, Malaysia, New Guinea, Papua New Guinea, Philippines

\section{Himantocladium plumula (Nees) M. Fleisch.}

Tacking trail to Mount WanggametiAlt. $1126 \mathrm{~m}$ and Laiwangi site, S $10^{\circ} 02^{\prime} 16.7^{\prime \prime}$ E $120^{\circ} 03^{\prime 2} 28.5^{\prime \prime}$ Alt. 563 m, on tree root and rock, DR $335 \& 523$

Malesiana Distr. Borneo, Java, Lesser Sunda Island (Bali, Lombok, Flores), Malaysia, Papua New Guinea, Philippine, Sumatra.

\section{Neckeropsis gracilenta (Sande Lac.) M. Fleisch.}

Tacking trail to Mount WanggametiAlt. $1133 \mathrm{~m}$, on bark, DR 341
Malesiana Distr. Borneo, Java, Lesser Sunda Islands ( Lombok, Flores ) Malaysia, New Guinea, Philippines, Sumatra

Neckeropsis lepineana (Nees.) M. Fleisch.

Tracking trail to Mount WanggametiS 1004'35.4" E $120^{\circ} 15^{\prime} 21.8^{\prime \prime}$, Alt. 1112-1153 m, on bark, DR $326 \& 364$

Malesiana Distr. Borneo, Celebes, Java, Lesser Sunda Islands (Bali, Lombok, Sumbawa, Flores, Timor), Malaysia, Papua New Guinea, Philippines, Sumatra

\section{Octoblepharaceae}

Octoblepharum albidum Hedw.

Laiwangi site, S 1003'46.7" E $120^{\circ} 04^{\prime} 21.7^{\prime \prime}$ Alt. 375 m and Wanggameti site, Alt. $1156 \mathrm{~m}$, on bark \& decaying wood, DR 351, 505

Malesiana Distr. Borneo, Java, Lesser Sunda Islands (Sumbawa, Flores, Timor, Komodo), New Guinea, Philippines

\section{Polytrichaceae}

Pogonatum neesii (Müll. Hal.) Dozy

Roadside to LaiwangiWanggameti National Park, Alt. $1024 \mathrm{~m}$, on soil, DR 314

Malesiana Distr. Borneo, Celebes, Java, Lesser Sunda Islands (Bali, Sumbawa, Flores, Timor), Malay Peninsula, Papua New Guinea, Philippines, Sumatra

\section{Pottiaceae.}

* Barbula convoluta Hedw.

Laiwangi region, S 1001'21.2" E 12003'26.3" Alt. 491

$\mathrm{m}$, on soil near waterfall, DR493

Malesiana Distr. Papua New Guinea

* Barbula consanguinea (Thw. \& Mitt.) A. Jaeger

Laiwangi, S 1001'21.2" E 12003'26.3" Alt. $491 \mathrm{~m}$, on soil near waterfall, DR 495

Malesiana Distr. Borneo, Celebes, Java, Malaysia, New Guinea, Philippines, Singapore, Sumatra

\section{Pterobryaceae}

* Calyptothecium crispulum ( Sande Lac.) Broth.

Tacking trail to Mount Wanggameti, Alt. 1156 m, on bark, DR 348

Malesiana Distr. Borneo, Celebes, Java, Papua New Guinea, Philippines, Sumatra

* Endotrichella elegans (Dozy \& Molk.) M. Fleisch.

Tracking trail to Mount WanggametiAlt. $1156 \mathrm{~m}$, on bark, DR 352

Malesia Distr. Java, Malacca, Sumatra

Pterobryopsis crassicaulis (Müll. Hal.) M. Fleisch.

Tracking trail to Mount Wanggameti, Alt. 1157 m, on bark, DR 366

Malesia Distr. Borneo, Java, Lesser Sunda Islands (Flores), Malaysia, Philippines, Sumatra 


\section{Rhizogoniaceae}

Pyrrhobryum spiniforme Hedw.

Tracking trail to Mount Wanggameti, Alt. 1114-1124 m and top of Mount WanggametiS 10 06'59.1" $\mathrm{E}$ $120^{\circ} 14^{\prime} 11.4^{\prime \prime}$ Alt. $1225 \mathrm{~m}$, on tree root, soil and rock, DR $328,334,418$

Malesiana Distr. Borneo, Celebes, Java, Lesser Sunda Islands (Bali, Lombok, Sumbawa, Flores, Timor, Alor), Malaysia, New Guinea, Philippines, Sumatra

\section{Sematophyllaceae}

Taxithelium vernieri (Duby) Besch.

Laiwangi region, S $10^{\circ} 01^{\prime 2} 21.2^{\prime \prime}$ E $120^{\circ} 03^{\prime} 26.3^{\prime \prime}$ Alt. 491 $\mathrm{m} \& \mathrm{~S} 10^{\circ} 02^{\prime} 16.7^{\prime \prime} \mathrm{E} 120^{\circ} 03^{\prime} 28.5^{\prime \prime}$ Alt. $563 \mathrm{~m}$ on tree root $\&$ bark near waterfall, DR $482 \& 520$

This species can be recognized by its lanceolate leaves with entire margins and smooth perichaetial leaves. The alar cells were not well developed as on T. levieri (Camara 2011)

Malesiana Distr. Borneo, Java, Lesser Sunda Islands (Flores), Malay Peninsula, New Guinea, Philippines, Sumatra

Taxithelium kerianum (Broth.) M. Fleisch.

Laiwangi region, S 1001'93.6" E 12003'47.8" Alt. 521 $\mathrm{m}$, on tree root near Laputi river, DR 531

This species is characterized by the densely pinnate stems with short and somewhat complanate branches and comparatively small leaves with a short-acuminate apex, a coronate-papillose apical cell, elongate multi papillose laminal cells and scarcely inflated alar cells (Ramsay 2012)

Malesiana Distr. Borneo, Java, Lesser Sunda Islands (Bali, Flores), Malaysia, New Guinea, Philippines

\section{Splachnaceae}

* Tayloria borneensis Dix.

Laiwangi site, S 1001'21.2" E 12003'26.3", Alt. 491 $\mathrm{m}$, on soil near waterfall, DR 487

Malesiana Distr. Borneo and Sulawesi

\section{Thuidiaceae}

Thuidium plumulosum (Dozy \& Molk.) Dozy \& Molk.

Tracking trail to Mount Wanggameti, S $10^{\circ} 04^{\prime} 37.3^{\prime \prime} \mathrm{E}$

$120^{\circ} 15^{\prime} 21.0^{\prime \prime}$, Alt. 1024-1124 m

This species is very similar to T. cymbifolium in general appearance, but immediately separable by its pluripapillose leaf cells (Touw 2012)

Malesiana Distr. Borneo, Java, Lesser Sunda Islands (Bali, Flores), New Guinea, Philippines, Sumatra

\section{ACKNOWLEDGEMENTS}

Gratitude is conveyed to the head of the Research Center for Biology, Indonesian Institute of Science who provided the opportunity to conduct this research, the head of Laiwangi-Wanggameti National Park in Sumba Island and the staffs who had provided facilities for this research. Thanks are also conveyed to all parties who have helped improve this manuscript

\section{REFERENCES}

Bartram EB. 1939 Mosses of the Philippines Philippine J Sci 68 (1): 1437.

Beever JE. 2014. Fissidentaceae In: Heenan PB, Breitwieser I, Wilton AD. Flora of New Zealand-Mosses. Fascicle 8. Manaaki Whenua Press, Lincoln.

BTNLW [Balai Taman Nasional Laiwangi Wanggameti]. 2013. Statistik Taman Nasional Laiwangi Wanggameti. Balai Taman Nasional Laiwangi Wanggameti, Direktorat Jenderal Perlindungan Hutan dan Konservasi Alam, Kementerian Kehutanan, Sumba. [Indonesian]

Camara PEAS. 2011. A Re-circumscription of the moss Genus Taxithelium (Pylaisiadelphaceae) with a taxonomic revision of Subgenus Vernieri. Syst Bot 36 (1): 7-21

Darma IDP, Peneng IN. 2007. Fern inventorization in LaiwangiWanggameti National Park, East Sumba, Waingapu, NTT. Biodiversitas 8 (3): 242-248.

Eddy A. 1988. A Handbook of Malesian Mosses Volume 1. Natural History Museum Publications, London

Eddy A. 1990. A Handbook of Malesian Mosses Volume 2. Natural History Museum Publications, London

Eddy A. 1996. A Handbook of Malesian Mosses Volume 3 Natural History Museum Publications London

Enroth J. 1992. Notes on the Neckeraceae (Musci). 13. Taxonomy of the genus Himantocladium. Annales Botanici Fennici 29 (1): 79-88.

Frahm JP, Gradstein SR. 1991. An altitudinal zonation of tropical rain forests using bryophytes. J Biogeogr 18 (6): 669-678,

Gilmore SR. 2012. Australian Mosses Online. 36. Rhizogoniaceae: Pyrrhobryum. http://www.anbg.gov.au/abrs/Mosses_Online/ Rhizogoniaceae Pyrrhobryum.pdf. [30 October 2019].

He S. 2019. An Annotated Checklist and Atlas of the Mosses of Thailand. Missouri Botanic Gardens, USA.

Noguchi A. 1972. Mosses of Thailand. Linbergia 1 (3/4): 169-183

Ramsay HP. 2012. Australian Mosses Online. 14. Pylaisiadelphaceae: Taxithelium. http://www.anbg.gov.au/abrs/Mosses_Online/ Pylaisiadelphaceae Taxithelium.pdf, [31 October 2019].

Rosario RMD. 1979. Moss Flora of the National Botanic Gardens Philippine. Agriculture research center National Institute of Science and Technology. P Gil St, Manila

So ML 1995 Moss and Liverworts of Hongkong vol.1 Biology Department Hongkong Baptist University, Hongkong.

Touw A, 2012. Australian Mosses Online. 23. Thuidiaceae: Thuidium. http://www.anbg.gov.au/abrs/Mosses_online/Thuidiaceae_Thuidium. pdf, [October 2019]

Touw A. 1992. A Survey of The Mosses of The Lesser Sunda Islands (Nusa Tenggara) Indonesia. J Hattori Bot Lab 71: 289-366

Windadri F. 2019. Mosses diversity from Lombok Island, West Nusa Tenggara. IOP Conf Ser: Earth Environ Sci 308: 012074. DOI: 10.1088/1755-1315/308/1/012074

Zhu RL, So ML. 1995. Moss and Liverworts of Hongkong vol. 2. Biology Department, Hongkong Baptist University, Hongkong. 